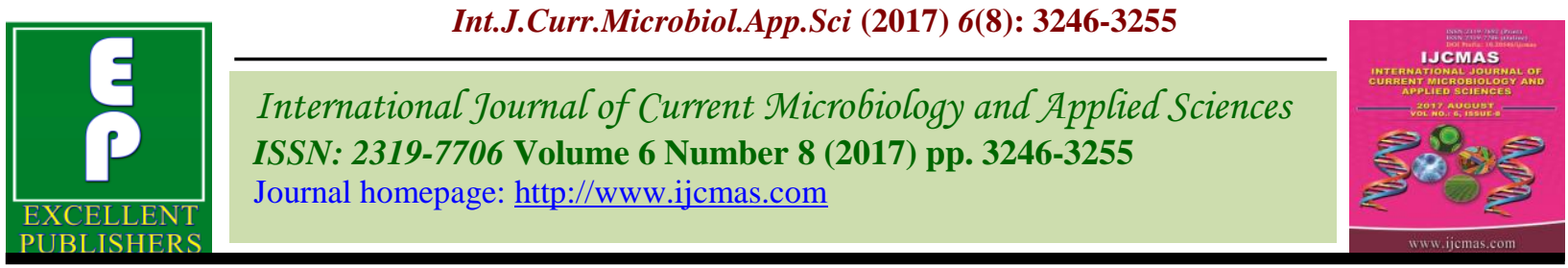

Review Article

https://doi.org/10.20546/ijcmas.2017.608.387

\title{
Vegetable Improvement in India; Recent Past, Present and Future: A Review
}

\author{
Aditika $^{1 *}$, Hardyal Singh Kanwar ${ }^{1}$, Priyanka $^{2}$ and Ankita Sharma ${ }^{1}$ \\ ${ }^{1}$ Department of Vegetable science, Dr YS Parmar University of Horticulture and Forestry, \\ Nauni, Solan-173 230, Himachal Pradesh, India \\ ${ }^{2}$ School of Agricultural Biotechnology, PAU Ludhiana-141004, Punjab, India \\ *Corresponding author
}

Ke y w o r d s
Vegetable,
Conventional
breeding,
Malnutrition,
Introgression and
multidisciplinary.
Article Info
Accepted:
26 June 2017
Available Online:
10 August 2017

\section{Introduction}

Vegetables are considered essential for wellbalanced diets since they supply vitamins, minerals, dietary fiber, and phytochemicals (Dias, 2013). Considering food and nutritional security vegetables play an important role in Indian agriculture. They are commonly called "protected food" because of their protective effects against degenerative diseases. Vegetables are considered as nutraceutical food of the century (Rahal et al., 2014). Almost every vegetable is a source of specific bioactive compounds like vitamins, anthocynins, flavanoids, carotenoids and polyphenols. All these compounds have ability in disease prevention and reduction because of their antioxidant property. According to the latest reports, vegetables are grown over 9.5 million hectare with the production of 168.30 million tonnes (Anonymous, 2016). India is the largest producer of okra among vegetables and ranks $2^{\text {nd }}$ in the production of potatoes, onion, cauliflower, brinjal, and cabbage. The improvement of vegetable crops has until recently, been largely confined to conventional breeding approaches and such 
programmes rely as interspecific sexual hybridization of plants which have desirable heritable characteristics and on naturally or artificially induced random mutations. Improvements may be obtain by re-assorting which has been achieved through enhancing breeding technologies by randomly induced changes and by generation of totally new possibilities through biochemical engineering (Miflin, 2000). Therefore, integration of traditional breeding methods and biotechnological tools will be an optimistic strategy for crop improvement in the future (Dias, 2012). Present review is based on various achievements which had been made through conventional approach of breeding in recent past and advances in vegetable improvement through biotechnological tools in India to provide food and nutritional security.

\section{Need for Improvement}

Vegetable improvement has to address and satisfy the needs of both the consumer and the farmer (Dias, 2011). General objectives of vegetable improvement programme are different for farmers from consumers. More emphasis is being given for development of hybrids to exploit heterosis and to combine multiple diseases and stress resistance along with quality improvement of the produce to have more acceptability. Genetic improvement can be achieved through conventional as well as non-conventional approaches. In conventional breeding, progeny inherit genes for both desirable and undesirable traits from both parents. Breeders conserve desired characteristics and suppress undesirable one by repeatedly selecting meritorious individuals from each generation to be the parents of the next. In nonconventional breeding, encompasses essential all cell and tissue culture technique that assist in propagating studying and manipulating the plant gene without use of sexual cycle as well as use of molecular markers to assist for selection of phenotype on the basis of presence or absence of molecular marker.

\section{Major contributions of conventional vegetable breeding during recent past}

During the past few decades off season varieties has been developed in radish, tomato, onion, cabbage and carrot which has enabled the farmers to grow these vegetables round the year. Varieties of different vegetables which can be grown as off season has been enlisted in table 1 with special characteristics. A schedule of planting different carrot varieties presented in table no 2, with different sowing time has been prepared for year round availability of carrot (Kalia, 2015). Gynoecious sex form had been recognised from Korean gynomonoecious introduction 'Shogoin' (PI 220860), as a chance segregate (Peterson, 1960). This gynoecy had been transferred into tropical varieties of cucumber and four stable tropical gynoecious lines viz., 87-304-6, 87-316, 87319-12 and 87-338-15 were established (More and Seshadri, 1988). A parthenocarpic tropical gynoecious cucumber lines (PKG-1 series) were developed in Poona Khira background. Recently Pusa Seedless cucumber-6 first extra early variety has been developed which is a parthenocarpic gynoecious cucumber and suitable for protected conditions, available at http://icar.org.in/. Seedless watermelon is more preferred by consumers because there is no seed to spit out. Conventional way to produce seedless watermelon is use of triploid hybrids. First seedless watermelon was Pusa Bedana which was developed by crossing Tetra-2 as female parent (4X) and Pusa Rasal as male parent $(2 \mathrm{X})$. Recently other varieties of seedless watermelon have been developed in India are Arka Madhura which is suitable for year round production under protected cultivation, Swarna and Shonima have been 
developed by crossing a stable tetraploid line of watermelon 'KAU-CL-TETRA-1'(4X) with diploid males (2X) namely, CL-4 (red fleshed) and CL-5 (Yellow fleshed), respectively (ICAR 2015). Farmers started shifting from open pollinated varieties to $F_{1}$ hybrids because of their superiorities over open pollinated varieties in several vegetables like in cabbage, tomato, capsicum, cucumber, melons and cauliflower. Earlier hand emasculation and hand pollination was the most popular method of hybrid seed production but this method is not economic in the crops where very less seed will produce with each hand pollination; so the cost of hybrid seed can be brought down if practically applicable mechanisms are available to avoid selfing and maximize out crossing in the hybrid seed production field (Kumar and Singh, 2004).

Production of hybrid seed at commercial level has become economic with the availability and exploitation of several genetic mechanisms like male sterility, selfincompatibility and gynoecism in several vegetable crops. In India many $F_{1}$ hybrids has been develop by utilizing all these mechanisms at commercial scale in few vegetable crops (table 3 ). There are different nutraceutical compounds present in vegetable crops (table no. 4) which can be defined as food or part of food having health benefits (DeFelice, 2002). Natural pigments present in plant tissue are called as edible colours and these include anthocyanins, betalains, carotenoids, chlorophylls.

These pigments play important metabolic functions in the plants are more frequently exploited as the source of nutraceuticals to address a number of human ailments (Grotewold, 2006). In India work is being done to exploit these bioactive compounds as well as edible colours to develop new varieties as a natural way to reduce the risk of various chronic diseases (table 5). Different breeding methods like recurrent selection, back cross, pedigree, mutation breeding, polyploidy breeding and development of $F_{1}$ hybrids are suitable for enhancing nutraceuticals and edible colours. The betacarotene content in muskmelon has increased manifold in $\mathrm{F}_{1}$ hybrid (Moon et al., 2002). Since long in India work is being done for the development of resistance varieties for biotic stresses as resistance varieties had been realized as a better option for sustainable crop production. Plenty of varieties were developed and has been listed by Kalloo (1998), Singh and Chaubey (2013), Meena and Meena (2014). In tomato multiple resistance for tomato leaf curl virus + bacterial wilt + early blight is at the acme of improvement. Arka Rakshak variety of tomato is a paradigm of multiple resistance breeding.

\section{Biotechnology as a tool for improvement of vegetable crops: Present Need}

Mushrooming population, subsiding agricultural resources; land and water, people's concern towards quality of vegetables/food and changing climate which possess several challenges for vegetable production; conventional breeding alone which is slow mean of improvement can no longer sustain the nation's as well as global demand. So there is an urgent need to adopt modern plant breeding which is a multidisciplinary and coordinated approach of improvement where a large number of tools and elements of conventional breeding technique, genetic engineering, molecular biology, molecular genetics bioinformatics and biochemistry are utilized and integrated.

Biotechnological tool provide three major aspects of genetic improvement through genetic engineering, molecular breeding or marker assisted breeding and tissue culture. 


\section{Transgenic or Genetically modified crop}

India ranks fourth position at global level for area under GM crop and solely covered by btcotton (11.6 million hectares) after USA, Brazil and Argentina (Anonymous, 2015). Although ban has been imposed on the release of first GM food crop (brinjal) in India available at Nature http://doi.org/bkt7dh; 2010, due to anti-GM group and public protests, albeit research is under process in several vegetable crops for enhancing nutritional value, mitigating biotic, abiotic stresses and their successful adoption is being expected in near future.

During recent past two years GM crop field trials are under practice in eight states that includes transgenic rice, cotton, maize (corn), mustard, brinjal and chickpea (Kumar, 2015). Pioneer public institutions which are working to strengthen the research under transgenic crops in India are National Centre for Plant Genome Research (NCPGR now NIPGR), ICAR- Indian Institute of Horticulture Research Hesaraghatta Bengaluru, Indian Institute of Vegetable Research, Varanasi and ICAR-Indian Institute of Agriculture Research. Transgenic tomato has been developed by utilizing a novel gene, PjVP1 cloned from a hardy plant Prosopis juliflora. The selected transgenic tomato line has shown enhanced drought and salinity tolerance and had higher yield as compared to control under drought and salinity stress IIHR annual report, 2015, available at www.iihr.res.in/content/annual-reports.

In Network Project on Transgenic Crops (NPTC), water-deficit stress tolerant transgenic tomato was developed using AtDREB1A gene. High level of fruit and shoot borer was observed in brinjal (Solanum melongena) cv. Kashi Taru plants due to high level of expression of CrylAa3 protein, Annual Report IIVR, 2012-13 available at www.iivr.org.in/annual-reports. Trial conducted using $\mathrm{T}_{4}$ progeny of transgenic watermelon cv. Arka Manik resistance to watermelon bud necrosis virus; all the tested transgenic lines were completely resistance to the disease, IIHR Annual Report, 2012 also available at www.iihr.res.in/content/annualreports. ProTato which is a transgenic potato line has $48 \%$ of increased overall protein content than non-transformed potatoes due to the expression of AMAl gene (Chakraborty et al., 2010).

Table.1 Varieties can be grown in off season

\begin{tabular}{|l|l|l|}
\hline Crop & Variety & Character \\
\hline Tomato & Ostenkinskiz, Cold Set, Pusa Sheetal & Fruit set at low temperature \\
\cline { 2 - 3 } & Hot Set, HS 102, Pusa Hybrid 1 & Fruit set at high tempetrature \\
\hline Radish & Pusa Chetki, Pusa Desi & $\begin{array}{l}\text { Made possible to grow throughout } \\
\text { year }\end{array}$ \\
\hline Onion & $\begin{array}{l}\mathrm{N} \mathrm{53,} \mathrm{Agrifound} \mathrm{Dark} \mathrm{Red,} \mathrm{Arka} \mathrm{Kalyan,} \\
\text { Baswant 780 }\end{array}$ & Kharif season \\
\hline Cabbage & $\begin{array}{l}\text { Green Express, Green Boy, KK Cross, Pusa } \\
\text { Ageti }\end{array}$ & Tolerance to high temperature \\
\hline
\end{tabular}


Table.2 Varieties of carrot for round the year cultivation

\begin{tabular}{|l|l|l|l|}
\hline Variety & Sowing time & Availability & Yield (q/ha) \\
\hline Pusa Vrishti & July-August & October-Nov. & $180-200$ \\
\hline Pusa Meghali & August & Nov.-Dec. & 220 \\
\hline Pusa Rudhira, Pusa Asita, Pusa Vasuda & Sep.-Oct. & Dec.-Jan. & $300-350$ \\
\hline Pusa Yamdagini, Pusa Nayanjyoti & Sep.-Nov. & Dec.-Feb. & $270-320$ \\
\hline Pusa Yamdagini & Dec.-Feb. & March-May & $200-250$ \\
\hline $\begin{array}{l}\text { Pusa Yamdagini, Pusa Nayanjyoti, Nantes, } \\
\text { Pusa Vrishti }\end{array}$ & March-April & June- July & $130-150$ \\
\hline
\end{tabular}

Table.3 Hybrids developed by exploiting genetic mechanisms

\begin{tabular}{|l|l|l|}
\hline Crop & F $_{\mathbf{1}}$ yybrid & Genetic Mechanism \\
\hline Cabbage & KGMR-1(Pusa cabbage Hybrid 1), KTCBH 51, KTCBH 81 & Self-incompatibility \\
\hline Cauliflower & Pusa Hybrid-2, Pusa Kartik Sankar & Self-incompatibility \\
\hline Cabbage & KCH-5, Hybrid 991-5, Hybrid 854-6 & Cyoplasmic male sterility \\
\hline Cauliflower & Hybrid 8401 ×31022 & Ctoplasmic male sterility \\
\hline Chilli & $\begin{array}{l}\text { Arka Sweta, Arka Meghna, Arka Harita, Arka Khyati, } \\
\text { Kashi Surkh, CH-1, CH-3 }\end{array}$ & $\begin{array}{l}\text { Cyto genic male Sterility and } \\
\text { Genetic male sterility }\end{array}$ \\
\hline Onion & Arka Kirthiman, Arka Lalima & Cytoplasmic male sterility \\
\hline Carrot & Pusa Nayanjyoti, Pusa Vasudha & Cytoplasmic male sterility \\
\hline Cucumber & Solan Khira Hybrid-1, Solan Khira Hybrid-2 & Gynoecious based F Fybrids $_{1}$ \\
\hline
\end{tabular}

Table.4 Different nutraceutical compounds in vegetable crops

\begin{tabular}{|l|l|}
\hline Vegetables & Nutraceutical/bioactive compounds \\
\hline Allium vegetables (garlic, onions, chives, leeks) & Allyl sulphides \\
\hline $\begin{array}{l}\text { Cruciferous vegetables (broccoli, cauliflower, cabbage, Brussels } \\
\text { sprouts, kale, turnips, kohlrabi) }\end{array}$ & $\begin{array}{l}\text { Indoles/glucosinolates, Sulforaphane } \\
\text { Isothiocyanates/thiocyanates, Thiols }\end{array}$ \\
\hline Solanaceous vegetables, (tomatoes, peppers) & Lycopene \\
\hline Umbelliferous vegetables (carrots, celery, parsley, parsnips) & Carotenoids,Phthalides,Polyacetylenes \\
\hline Compositae plants (artichoke) & Silymarin \\
\hline Beans & Flavonoids (isoflavones) \\
\hline $\begin{array}{l}\text { Carrots, squash, broccoli, sweet potatoes, tomatoes, kale, } \\
\text { collards, cantaloupe and pumpkin }\end{array}$ & Vitamin A (retinol) \\
\hline $\begin{array}{l}\text { Green peppers, broccoli, green leafy vegetables, cabbage and } \\
\text { tomatoes }\end{array}$ & Vitamin C (ascorbic acid) \\
\hline Green leafy vegetables & Vitamin E \\
\hline
\end{tabular}

Table.5 Varieties rich in bioactive and edible colour in India

\begin{tabular}{|l|l|l|}
\hline Crop & Variety & Pigment \\
\hline Carrot & Pusa Ashita & Anthocyanin \\
\hline Paprika & KTPL-19 & Capsanthin \\
\hline Amaranthus & Pusa Lal Chaulai & Anthocyanin \\
\hline Red cabbage & Red Cabbage & Anthocyanin \\
\hline Purpule headed Broccoli & Palam Vichitra & Anthocyanin \\
\hline \multirow{3}{*}{ Carrot } & Pusa Rudhira & Lycopene \\
\cline { 2 - 3 } & Pusa Vrishti & Lycopene \\
\cline { 2 - 3 } & Pusa Yamdagini & Carotene \\
\cline { 2 - 3 } & Pusa Nayanjyoti & Carotene \\
\hline
\end{tabular}


Table.6 Sequenced Genome of Vegetable Crops

\begin{tabular}{|l|l|l|l|l|}
\hline S. No. & Crop & $\begin{array}{l}\text { Haplod } \\
\text { chr. No. }\end{array}$ & $\begin{array}{l}\text { Estimated genome } \\
\text { size } \mathbf{( M b})\end{array}$ & References \\
\hline 1 & Cucumber & 7 & 367.00 & Huang et al., 2009 \\
\hline 2 & Musk melon & 12 & 450.00 & Gonzalez et al., 2010 \\
\hline 3 & Potato & 12 & 844.00 & $\begin{array}{l}\text { The potato genome sequencing } \\
\text { consortium 2011 }\end{array}$ \\
\hline 4 & Chinese cabbage & 10 & 529.00 & $\begin{array}{l}\text { The Brassica rapa genome } \\
\text { Sequencing project consortium } \\
2011\end{array}$ \\
\hline 5 & Tomato & 12 & 900.00 & $\begin{array}{l}\text { The tomato genome consortium } \\
2012\end{array}$ \\
\hline 6 & Water melon & 11 & 425.00 & Gau et al., 2013 \\
\hline 7 & Brinjal & 12 & 1126.00 & Hirakawa et al., 2014 \\
\hline 8 & French bean & 11 & 587.00 & Schmutz et al., 2014 \\
\hline 9 & Chilli & 12 & 3480.00 & Kim et al., 2014 \\
\hline 10 & Cabbage & 9 & 630.00 & Liu et al., 2014 \\
\hline 11 & Pumpkin & 20 & 271.4 & Zhang et al., 2015 \\
\hline 12 & Carrot & 18 & 473 & Iorizzo et al., 2016 \\
\hline
\end{tabular}

Molecular assisted breeding to fasten the vegetable improvement programme

Molecular marker or DNA markers are the short DNA sequences whose inheritance can easily be monitored and detected. Potential application of molecular markers in vegetable crop has been reviewed by Ansari (2015). Use of molecular markers in breeding has opened a new horizon called marker assisted breeding. Marker assisted selection is the selection for a trait based on genotype using associated markers rather than the phenotype of the trait (Foolad and Sharma, 2005). Marker assisted selection improve the efficiency and speed up the selection during breeding cycles (Holland, 2015). Gene pyramiding for the creation of multi-resistant varieties has been made possible with the development of molecular markers (Melchinger, 1990). A fertility restorer and male sterile gene has been tagged through RAPD protocol in chilli (Kumar et al., 2002). For the first time in Indian long day onion population, DNA marker for male sterility and hybrid development has developed and identified with the help of which we can exploit the identified marker in future for hybrid development as well as transfer of male sterility to other onion lines or genotypes through marker assisted selections (Saini et al., 2015). Marker assisted selection has been employed in tomato for the introgression of Ty2 and Ty3 genes to develop tomato leaf curl resistant hybrid (Prasanna et al., 2015).

\section{Tissue culture}

Tissue culture provides a wide scope for the rapid multiplication of true to types, virus free propagating material through meristem culture and maintenance of healthy stocks. Unlike gametic fusion, somatic fusion provides a mean of asexual hybridization of two protoplasts from somatic cells in order to combine complete two genomes at intra- and interspecific and intra- and/ or intergeneric levels (Pandey et al., 2010). Somatic hybrids of C-13 (+) S. pinnatisectum have shown resistance to late blight under field and in vitro conditions (Tiwari et al., 2013). Specified MS medium was used for in vitro conservation of potato cultivars; Kufri Jyoti, 
Phulwa and C-13, from where true to types could be regenerated for the production of healthy seed stock (Tiwari et al., 2015). Double haploids used for cultivar development in self-fertilizing species and for the development of inbreds in cross fertilizing species (Dwivedi et al., 2015).

Next generation genome sequencing: Unveiling an endeavour of vegetable improvement

Next generation genome sequencing provide opportunities of getting high density genetic maps which predict the linear arrangement of markers in a chromosome, identification of agronomically important genes and development of millions of novel markers (Edward and Batley, 2010). Genes governing different traits can be identified through sequence data obtain from genome and transcriptomes along with their expression profile which are associated with different physiological conditions, data obtained also crucial for successful breeding programme by enabling the identification of allelic variation in candidate genes controlling important agronomic traits (Thottathil, 2016). Vegetable crops which have been sequenced till today are presented in table no. 6 , would enable us to develop new varieties which are tolerant to biotic, abiotic stresses and with improved quality traits through systematic mining and utilization of this data obtained.

\section{Future need for improvement}

Although India is the leading producer for many vegetable including other food crops, however, forty three per cent of Indian children fewer than five years are underweight and 48 per cent (i.e. 61 million children) are stunted due to chronic under nutrition, India accounts for more than 3 out of every 10 stunted children in the world, available at http://unicef.in. Estimated 15\% population is undernourished and lacks in adequate food intake, both in quantity and quality. It is somewhat shocking to know that India is ranked lower than some sub-Saharan African countries, Nepal, Bangladesh, Sri Lanka and China in Global Hunger Index, available at http://www.ifpri.org/. It is distressing for the nation that India has slipped from $83^{\text {rd }}$ position in 2000 to $97^{\text {th }}$ position in 2016 among 118 countries, so great responsibilities ought to be on the shoulder of breeders. Although main breeding objective will continue to be increasing yield to meet the food requirement of ever increasing population, but in order to ensure health security, it is imperative that nutrition rich varieties are breed. We had attained selfsufficiency in food grains through conventional breeding approach but now there is a need for second green revolution where not only production/yield alone but quality food is the major breeding objective, this cannot be realized alone with conventional as well as biotechnological approach alone, so we have to find a mid-way where we will integrate these two novel approaches for vegetable improvement. In India the research work is at its embryonic stage but there is a great potential of integrating data available at DNA level to its phenotypic level to make realistic selection by the breeders. We can envisage future vegetable crops with higher stress tolerance, wider adaptability, higher nutritional contents and with improved processing quality. Conventional breeding in conjunction with molecular biology has bright prospects of developing vegetable varieties with high nutraceuticals and bio active compounds suitable for fresh market.

\section{References}

Anonymous, 2015. Global area under GM crops. International Service for the Acquisition of Agri-Biotech Application (ISAAA). 
Anonymous, 2015. National Horticulture Board, Gurgaon, Haryana.

Ansari A. M., 2015. Molecular markers in vegetable improvement. Horticultural Biotechnology Research 1: 5-10.

Chakraborty S, Chakraborty N, Agrawal L, Ghosh S, Narula K, Shekhar S, Naik P. S., Pandey P. C., Chakrborti S. K., Datta A., 2010. Next-generation protein-rich potato expressing the seed protein gene AmAl is a result of proteome rebalancing in transgenic tuber. PANS 107(41): 17533-17538.

DeFelice S. L., 2002. FIM, Rationale and Proposed Guidelines for the Nutraceutical Research \& Education Act NREA, Foundation for Innovation in Medicine. Available at: http://www.fimdefelice.org/archives/arc .researchact.html, November 10, 2002.

Dias J. S., 2013. Vegetable breeding for nutritional quality and health benefits; Cultivars: chemical properties, antioxidant activities and health benefits Carbon K (editor). Nova Science Publishers Inc., New York pp 1-82.

Dias J. S., Ryder E. J., 2011. World vegetable industry: Production, breeding, trends. Horticulture Reviews 38: 300-356.

Dias S, Ortiz R., 2012. Transgenic vegetable breeding for nutritional quality and health benefits. Food and Nutrition Sciences 3: 1209-1219.

Dwivedi S. L., Britt A. B., Tripathi L., Sharma S., Upadhyaya H. D., Ortiz R., 2015. Haploids: Constraints and opportunities in plant breeding. Biotechnology Advances 33: 812-829.

Edwards D., Batley J., 2010. Plant genome sequencing: Applications for crop improvement. Plant Biotechnology Journal 8(1): 2-9.

Foolad M. R., Sharma A., 2005. Molecular Markers as Selection Tools in Tomato Breeding. Acta Horticulturae 695: 225240.
Gonzalez V. M., Benjak A., Henaff E. M., Mir G., Casacuberta J. M., Garcia-Mas J, Puigdomenech P., 2010. Sequencing of $6.7 \mathrm{Mb}$ of the melon genome using a BAC pooling strategy. BMC Plant Biology 10: 246.

Grotewold E., 2006. The genetics and biochemistry of floral pigments. Annual Review of Plant Biology 57: 761-780.

Guo S, Zhang J, Sun H, Salse J, Lucas W. J., Zhang H., Zheng Y., 2013. The draft genome of watermelon (Citrullus lanatus) and resequencing of 20 diverse accessions. Nature Genetics 45: 51-58.

Hirakawa H, Shirasawa K, Miyatake K, Nunome T, Negoro S, Ohyama A Yamaguchi $\mathrm{H}$ et al., 2014. Draft genome sequence of eggplant (Solanum melongena L.): The representative solanum species indigenous to the old world. DNA Research 21(6): 649-660.

Holland J. B., 2014. Implementation of Molecular Markers for Quantitative Traits in International Service for the Acquisition of Agri-Biotech Application, 2015. Global Status of Commercialized Biotech/GM Crops: 2014.

Huang S., Li R., Zhang Z., Li L., Gu X., Fan W., Lucas W. J., 2009. The genome of the cucumber, Cucumis sativus $\mathrm{L}$. Nature Genetics 41(12): 1275-1281.

ICAR-Indian Institute of Vegetable Research, Vegetable Newsletter, January- June 2015, 2, 6, Available at http://www.iivr.org.in.

Iorizzo M., Ellison S., Senalik D., Zeng P., Satapoomin P., Huang J., Bowman M., Iovene M., Sanseverino W., Cavagnaro P., Yildiz M., Podgórni A. M., Moranska E., Grzebelus E., Grzebelus D., Ashrafi H., Zheng Z., Cheng S., Spooner D., Deynze A. V. and Philipp Simon, 2016. A high-quality carrot genome assembly provides new insights into carotenoid accumulation and 
asterid genome evolution. Nature Genetics 2016; doi:10.1038/ng.3565

Kalia P., Saha S., Sureja A. K., 2015. Growing carrot year round is lucrative. Indian Horticulture, July- August, 2015, Available at www.icar.org.in.

Kalloo G., 1998. Vegetable research in India. Indian Journal of Agriculture Sciences 68(8 Special issue): 515-526.

Kim S., Park M., Yeom S. I., Kim Y. M., Lee J. M., Lee H. A., Seo A., 2014. Genome sequence of the hot pepper provides insights into the evolution of pungency in Capsicum species. Nature Genetics 46(3): 270-278.

Kumar S., 2015. India eases stance on GM crop trials: States begin to permit field tests of transgenic plants. Nature 521: 138.

Kumar S., Singh P. K., 2004. Mechanisms for Hybrid Development in Vegetables. Journal of New Seeds 6(4): 300-407.

Kumar S., Singh V., Kumar S., Rai M., Kalloo G., 2002. Rapd protocol for tagging of fertility restorer and male sterility genes in chilli (Capsicum annuum L.). Vegetable Science 29(2): 101-105.

Liu S., Liu Y., Yang X., Tong C., Edwards D., Parkin I. A., Zhao M., et al., 2014. The Brassica oleracea genome reveals the asymmetrical evolution of polyploid genomes. Nature Communications, 2014, 5, 3930 . doi:10.1038/ncomms4930.

Meena O. P., Meena N. K., 2014. Role of hybrids in vegetable production. Popular Kheti, 2(3): 7-14.

Melchinger A. E., 1990. Use of molecular markers in breeding for oligogenic disease resistance. Plant Breeding 104: 1-19.

Miflin B., 2000. Crop improvement in the $21^{\text {st }}$ century. Journal of Experimental Botany 5(342): 1-8.

Moon S. S., Verma V. K., Munshi A. D.,
2002. Gene action of quality traits in muskmelon (Cucumis melo L.). Vegetable Science 29 (2): 134-136.

More T. A., Seshadri V. S., 1998. Development of tropical gynoecious lines in cucumber. Cucurbit Genet. Coop. Rep. 11: 17-18.

Pandey S. K., Sarkar D., Sharma S., Chandel P., 2010. Integration of somatic fusion into potato breeding: problems and perspectives. Potato Journal 37(1-2): 920.

Peterson C. E., Anhder L. D., 1960. Induction of staminate flowers on gynoecious cucumber with gibberellin $\mathrm{A}_{3}$. Science 131: 1673-1674.

Prasanna H. C., Kashyap S. P., Krishna R., Sinha D. P., Reddy S., Malathi V. G., 2015. Marker assisted selection of Ty-2 and Ty-3 carrying tomato lines and their implications in breeding tomato leaf curl disease resistant hybrids. Euphytica 204: 407-418.

Rahal A., Mahim, Verma A. K., Kumar A., Tiwari R., Kapoor S., Chakraborty S. C., Dhama K., 2014. Pytonutriants and nutraceutical in vegetables and their multi-dimentional medicinal and health benefits for human and their companion animals: A Review. Journal of Biological Science 14(1): 1-19.

Saini N., Hedau N. K., Khar A., Yadav S., Bhatt J. C., Agrawal P. K., 2015. Successful deployment of marker assisted selection (MAS) for inbred and hybrid development in long-day onion (Allium cepa L.). Indian Journal of Genetics 75(1): 93-98.

Schmutz J, McClean P. E., Mamidi S., Wu G. A., Cannon S. B., Jenkins J, et al., 2014. A reference genome for common bean and genome-wide analysis of dual domestications. Nature Genetics 46(7): 707-713. doi:10.1038/ng.3008.

Singh B., Chaubey T., 2013. Vegetable research in India: An overview. 
Progressive Horticulture 45: 9-35.

The Brassica rapa Genome Sequencing Project Consortium, 2011 The genome of the mesopolyploid crop species Brassica rapa. Nature Genetics 43(10): 1035-1039.

The Potato Genome Sequencing Consortium, 2011. Genome sequence and analysis of the tuber crop potato. Nature 475(7355): 189-195.

The Tomato Genome Consortium, 2012. The tomato genome sequence provides insights into fleshy fruit evolution. Nature 485(7400): 635-641.

Thottathil G. P., Jayasekaran K., Othman A. S., 2016. Sequencing Crop Genomes: A Gateway to Improve Tropical Agriculture. Tropical Life Sciences Research 27(1), 93-114.

Tiwari J. K., Gupta S., Gopal J., Kumar V.,
Bhardwaj V., Singh B. P., 2015. Molecular analysis of genetic stability of in-vitro conserved potato microplants. Potato Journal 42(2): 137145.

Tiwari J. K., Poonam, Kumar V., Singh B. P., Sharma S., Luthra S. K., Bhardwaj, V., 2013. Evaluation of potato somatic hybrids of dihaploid s. Tuberosum (+) s. Pinnatisectum for late blight resistance. Potato Journal 42(2): 176-179.

Zhang G., Ren Y., Sun H., Guo S., Zhang F., Zhang J., Zhang H., Jia Z., Fei Z., Xu Y., Li, H., 2015. A high-density genetic map for anchoring genome sequences and identifying QTLs associated with dwarf vine in pumpkin (Cucurbita maxima Duch.). BMC Genomics, 2015, 16:1101 DOI 10.1186/s12864-015$2312-8$.

\section{How to cite this article:}

Aditika, Hardyal Singh Kanwar, Priyanka and Ankita Sharma. 2017. Vegetable Improvement in India; Recent Past, Present and Future: A Review. Int.J.Curr.Microbiol.App.Sci. 6(8): 32463255. doi: https://doi.org/10.20546/ijcmas.2017.608.387 